Fish and Fisheries

September 2016, Volume 17, Issue 3, Pages 803-824

http://dx.doi.org/10.1111/faf.12147

http://archimer.ifremer.fr/doc/00312/42305/

(C) 2016 John Wiley \& Sons Ltd

\title{
A comparative review of fisheries management experiences in the European Union and in other countries worldwide: Iceland, Australia, and New Zealand
}

\author{
Marchal Paul ${ }^{1,{ }^{*}}$, Andersen Jesper Levring ${ }^{2}$, Aranda Martin ${ }^{3}$, Fitzpatrick Mike ${ }^{4,5}$, Goti Leyre ${ }^{6}$, \\ Guyader Olivier ${ }^{7}$, Haraldsson Gunnar ${ }^{8}$, Hatcher Aaron ${ }^{9}$, Hegland Troels Jacob ${ }^{10}$, Le Floc h Pascal ${ }^{11}$, \\ Macher Claire ${ }^{7}$, Malvarosa Loretta ${ }^{12}$, Maravelias Christos D ${ }^{13}$, Mardle Simon ${ }^{2}$, Murillas Arantza ${ }^{3}$, \\ Nielsen J Rasmus ${ }^{14}$, Sabatella Rosaria ${ }^{12}$, Smith Anthony D M ${ }^{15}$, Stokes Kevin ${ }^{16}$, \\ Thoegersen Thomas ${ }^{14}$, Ulrich Clara ${ }^{14}$
}

${ }^{1}$ Channel and North Sea Fisheries Research Unit; IFREMER; 150 Quai Gambetta, BP 69962321 Boulogne s/mer, France

${ }^{2}$ Department of Food and Resource Economics; University of Copenhagen; Rolighedsvej 251985 Frederiksberg C, Denmark

${ }^{3}$ AZTI Tecnalia; Marine Research Division; Herrera; kaia. Portualdea z/g E-20110 Gipuzkoa, Spain

${ }^{4}$ Socio-Economic Marine Research Unit, J.E. Cairnes School of Business and Economics; National University of Ireland; Galway, Ireland

${ }^{5}$ Irish Observer Net 3 Burton Place; Gardiners Hill Cork, Ireland

${ }^{6}$ Thünen Institute of Sea Fisheries; Palmaille 922767 Hamburg, Germany

${ }^{7}$ Maritime Economy Unit; IFREMER; ZI Pointe du Diable, CS 1007029280 Plouzané ,France

${ }^{8}$ Institute of Economic Studies; University of Iceland; Oddi by Sturlugata 101 Reykjavik ,Iceland

${ }^{9}$ Economics and Finance Department, Portsmouth Business School; University of Portsmouth, Richmond Building; Portland Street Portsmouth PO1 3DE, UK

${ }_{10}^{1}$ Innovative Fisheries Management; Aalborg University; Skibbrogade 5 DK-9000 Aalborg,Denmark

${ }^{11}$ Unité Mixte de Recherche AMURE; Université de Bretagne Occidentale; 12 rue de Kergoat, Bât. B, CS 9383729238 Brest Cedex 3, France

${ }^{12}$ NISEA; Fishery and Aquaculture Research Organisation; Via Irno 1184135 Salerno SA, Italy

${ }_{13}^{13}$ Hellenic Centre for Marine Research; 46.7 km Athens-Sounio 19013 Anavyssos Attica, Greece

${ }^{14}$ Institute of Aquatic Resources; Technical University of Denmark; Jaegersborg Alle 12920

Charlottenlund, Denmark

${ }^{15}$ CSIRO Oceans and Atmosphere; GPO Box 1538 Hobart Tas. 7109 ,Australia

${ }^{16} 59$ Jubilee Road Khandallah Wellington 6035 ,New Zealand

* Corresponding author: Paul Marchal, Tel.: +33 321995600 ; Fax: +33 321995601 ;

email address : paul.marchal@ifremer.fr

\section{Abstract :}

This study compares the details and performance of fisheries management between the EU and a selection of other countries worldwide: Iceland, New Zealand, and Australia, which are considered in many respects to be among the most advanced in the world in fisheries management. Fisheries management in the EU, Iceland, Australia, and New Zealand has developed following different paths, 
despite being based on similar instruments and principles. Iceland, Australia, and New Zealand have been at the forefront of developing management practices such as stakeholder involvement, legally binding management targets (Australia, New Zealand), individual transferable quotas, and discard bans (Iceland, New Zealand). The EU has since the beginning of the 21st century taken significant steps to better involve stakeholders and establish quantitative targets through management plans, and a landing obligation is gradually being implemented from 2015 onward. The management of domestic fisheries resources in Australia, New Zealand, and Iceland has, overall, performed better than in the EU, in terms of conservation and economic efficiency. It should, however, be stressed that, compared to Australia, New Zealand, and Iceland, (i) initial over-capacity was more of an issue in the EU when management measures became legally binding and also that (ii) EU has been progressive in developing common enforcement standards, on stocks shared by sovereign nations. The situation of EU fisheries has substantially improved over the period 2004-2013 in the northeast Atlantic, with fishery status getting close to that in the other jurisdictions, but the lack of recovery for Mediterranean fish stocks remains a concern.

Keywords: Australia, comparative review, European Union, fisheries management, Iceland, New Zealand 


\section{Table of contents}

\section{Glossary}

Introduction

Management processes

Decision-making

Stakeholders' involvement

Science

Management objectives and strategies

Management tools

Conservation measures

Access regulations

Management performances

Conservation

Economics

Conclusions

Acknowledgements

References

\section{Glossary}

AC: $\quad$ (EU) Advisory Committee

ACE: (New Zealand) Annual Catch Entitlement

AFMA: Australian Fisheries Management Authority 
B: $\quad$ (Fish/Shellfish) Biomass

CFP: (European Union) Common Fisheries Policy

DLS: $\quad$ Data-Limited Stocks

EEZ: $\quad$ Exclusive Economic Zone

EU: $\quad$ European Union

F: $\quad$ Fishing mortality

GFCM: General Fisheries Committee for the Mediterranean Sea

GFT: Government Financial Transfer

HCR: Harvest Control Rule

HSP: $\quad$ (Australian) Harvest Strategy Policy

HSS: $\quad$ (New Zealand) Harvest Strategy Standards

IC-NZ-AU: Iceland, New Zealand and Australia

ICES: International Council for the Exploration of the Sea

IQ: $\quad$ Individual Quota

ITQ: $\quad$ Individual Transferable Quota

MAC: (Australian) Management Advisory Committee

MCS: $\quad$ Minimum Catch Size

MEY: $\quad$ Maximum Economic Yield 
MLS: $\quad$ Minimum Landing Size

MSY: $\quad$ Maximum Sustainable Yield

NMP: $\quad$ (Mediterranean) National Management Plan

PA: Precautionary Approach

PO: $\quad$ Producer Organisation

QMS: $\quad$ (New Zealand) Quota Management System

RAG: (Australian) Resource Assessment Group

SSB: $\quad$ Spawning Stock Biomass

STECF: (European Union) Scientific, Technical and Economic Committee for Fisheries

TAC: $\quad$ Total Allowable Catch

TACC: (New Zealand) Total Allowable Commercial Catch

\section{Introduction}

Fisheries management in developed countries worldwide has followed different paths, despite generally similar management principles. These management principles have been broadly agreed during international conferences, but introduced at national levels to varying degrees. The first of these worldwide conferences was the United Nations Conference on the Human Environment that was held in Stockholm in 1972. The Stockholm Declaration resulted in 26 principles concerning the environment and development, and put forward in particular the link between ecological 
management, economic development and social welfare (UN 1972). Twenty years later, the 1992 Rio Declaration on Environment and Development introduced the concept of sustainable development and the precautionary principle (UN 1992). The 2002 Johannesburg World Summit on Sustainable Development called for a stronger implementation of the general sustainable development principles that were brought forward in Stockholm and Rio (UN 2002). A major outcome of the 2002 World Summit was a Plan of Implementation, establishing some binding deadlines for achieving goals related to oceans and coasts that were endorsed by the signatories. Of particular relevance to fisheries management was the implementation of the ecosystem approach to fisheries by 2010, a significant reduction of the rate of biodiversity impairment by 2010, the establishment of a network of marine protected areas by 2012, and the achievement of the Maximum Sustainable Yield (MSY), wherever possible, by 2015. Finally, the political commitment engaged during previous Earth Summits was reaffirmed during the 2012 Rio Conference on Sustainable Development (UN 2012).

The degree and extent to which these principles and objectives were implemented at national or supra-national level by management agencies worldwide has been variable. The experience of EU fisheries management is unique in its scope and ambition, in that it represents the only example of reconciling the concerns of a variety of coastal countries and eco-regions with diverse, if not divergent, interests into a Common Fisheries Policy, the CFP. The EU CFP was first introduced in 1970, completed with the adoption of its conservation pillar in 1983 [Council Regulation (EEC) No. 170/83], and subsequently revised in 1992 [Council Regulation (EEC) No. 3760/92], 2002 [Council Regulation (EC) No. 2371/2002] and finally in 2013 [Regulation (EU) No. 1380/2013]. The last revision of the CFP is referred to as the 2013 CFP throughout the document. It is notable that

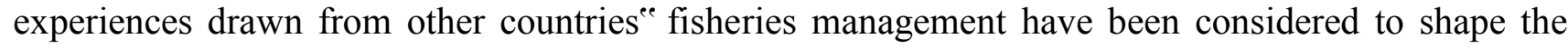
2013 CFP (van Hoof 2010), and these will likely be accounted for in reviewing future performance. Comparing the background, context and performance of management systems worldwide is particularly enlightening to inform EU fisheries managers. In the recent past, there has been only a 
limited number of reviews that compared specific fisheries management issues across a range of countries (Sanchirico et al. 2006), or compared fisheries management in a broader sense, but across a relatively limited number of regions and/or fisheries (Marchal et al. 2009; Large et al. 2013; Nielsen et al. 2013). Gascuel et al. (2014) have reviewed and compared management performance, in terms of ecosystem conservation, for a broad range of EU regions.

In this study, we will investigate and compare EU fisheries management applicable to the Northeast Atlantic and the Mediterranean with experiences drawn from several contrasted non-EU countries where we consider fisheries management to have been innovative. Several such countries could have been considered, e.g., Iceland, Australia, New Zealand, USA, Canada, Norway and South Africa. To keep our review to tractable size and in line with the authors ${ }^{e e}$ domain of expertise, we selected three countries from that list: Iceland, Australia and New Zealand, which have been pointed out for their well-functioning fisheries management (Motos and Wilson 2006; Hauge and Wilson 2009).

Fisheries in the EU, New Zealand, Australia and Iceland are managed essentially using a similar set of standard tools: commercial fishing vessels are licensed, key stocks (historically the most economically valuable and therefore most targeted) are assessed, and limitations are placed on the catch of those stocks through input controls (e.g. restricting capacity/effort or regulating gears) and/or output controls (e.g. restricting landings or catch) (Motos and Wilson 2006; Sanchirico et al. 2006; Marchal et al. 2009). Fisheries management uses these tools, embedded within a wider management system, to meet stock conservation objectives but also provides for objectives relating to the wider economy and ecosystem. The success of fisheries management is evaluated against the targets placed on these objectives, but is judged almost solely by the conservation status of the key stocks. The complexities of management reflect how these objectives fit into the decision making process. The difficulty of managing fisheries is particularly reflected in the targets assigned to conservation objectives and how management actions are taken to meet these objectives in the short-medium term through to the long term. However, it is typical of political systems that the short term view is 
prioritised over the long term (Holden 1994). Despite using common approaches, there is considerable contrast between the fisheries management systems of the European Union and of the other countries investigated.

The most obvious difference is that the EU consists of a variety of member states bound together with several supra-national institutions, while Iceland, New Zealand and Australia are sovereign countries. Total Allowable Catches (TACs) for the key EU stocks are agreed on a yearly basis, with each member state representing its own interests cognisant of allocation implications. A major principle of the EU CFP is the relative stability, essentially ensuring that each Member State is guaranteed a specified proportion of the key stocks ${ }^{e e}$ TACs. The administrative complexity of the EU system is highlighted here as agreement must be reached between the national governments represented at the Council of Ministers. The negotiation strategy of the different governmental delegations is informed by scientific advice, but it is also often influenced by discussions with a great variety of stakeholder groups arguing on behalf of their constituents. In Iceland, New Zealand and Australia, with only one country involved in each, this process is far less complicated even though the same issues are addressed and multiple stakeholders (and States in Australia) may be involved.

Some simple average indicators of the size of the EU system versus Iceland, New Zealand and Australia are presented in Table 1. For example, Iceland, New Zealand and Australia (IC-NZ-AU) have (on aggregate) $4 \%$ the number of vessels, $11 \%$ the employment in the harvest sector and $32 \%$ the landed value of the EU. Internal market demand (including imports) approximates US\$27 billion in the EU versus less than US\$1billion in IC-NZ-AU. This is in contrast to the total size of the Exclusive Economic Zones (EEZs) where the EU is only 1.5 times the size of IC-NZ-AU. The pressures on EU fisheries are therefore massively greater than in IC-NZ-AU, even when $84 \%$ of the EU fleet can be considered as small scale (Guyader et al. 2013).

This paper presents a comparative review of the fisheries management institutions and processes, objectives, strategies, and tools across the EU, Iceland, Australia and New Zealand. The relative 
performance of these different fisheries management systems will then be contrasted and discussed based on conservation and economic criteria. For the purpose of easing comparisons, the focus is on fleets targeting fish and shellfish species harvested either exclusively in EU waters or shared with a limited number of countries, where a multilateral management agreement exists (hereby referred to as domestic species and fisheries). Therefore, highly migratory species such as tunas, which are managed by specific Regional Fisheries Management Organizations, or Northeast Atlantic mackerel, for which no management agreement exists, are not considered. Also, this review generally does not address local management delivered by, e.g., individual EU member states (except in the Mediterranean Sea where it is prominent), or Australian states, within their waters of jurisdiction. Finally, to make our review more focused, we have restricted its scope to a comparison of fisheries resource management across the different jurisdictions, and we have not addressed broader ecosystem management aspects (e.g., impact of fishing activities on benthic invertebrates, seabirds, or sea mammals). Consideration will be given in the Conclusions section to the consequences of limiting the scope of this review to domestic fisheries, and also to ecosystem-based management prospects.

\section{Management processes}

\section{Decision-making}

Unlike Iceland, New Zealand and Australia, which are sovereign countries, the EU is a supra-national entity, where decision-making results from a negotiation between the Member States.

In the EU, decision-making involves three institutions: the Commission, which primarily initiates proposals for legislation; the Council, composed of representatives of the Member States in their area of competence, such as the Ministers of Fisheries, which decides upon the adoption of proposals from the Commission; and the Parliament, which has a legislative function. Until 2009, the Council had 
sole responsibility to take decisions on TACs and national quotas, technical measures and fishing effort restrictions, for most of the fisheries shared by several Member states. Since the 2009 Treaty of Lisbon, however, the system has moved towards a greater involvement of the Parliament and of the Commission in the decision-making process. In practice, however, this has created a new layer of complexity, which has rendered agreement on co-decision procedures difficult, thereby delaying the establishment of new fisheries management plans since 2009. With regard to North-East Atlantic fish stocks, TAC decisions have typically been based on scientific advice, mainly delivered by the International Council for the Exploration of the Sea (ICES), but also taking account of short-term socio-economic concerns of the industry. The overall agreed TAC is then divided between member states based on a fixed allocation key (Holden, 1994). Quota swaps between member states are possible, and maintain some flexibility in the TAC system after the allocation is made. With regard to Mediterranean demersal and small pelagic fisheries, the GFCM, the EU (as contracting party of the GFCM) and national states share decision-making responsibilities. EU Regulation 1967/2006 that entered into force in 2007, has promoted a different approach to fisheries management based on decentralized decision-making, both at national and community levels.

In Iceland, most decisions regarding fisheries operational management, including TAC-setting, are taken by the Ministry of Fisheries and Agriculture, based on scientific recommendations from the Marine Research Institute (MRI).

In New Zealand, final decisions on the majority of Regulations, all TAC setting and allocation, are made by the Minister for Primary Industries. In setting the TAC, the Minister must make allowances for customary (Maori) use, recreational take and other sources of fishing mortality. The Total Allowable Commercial Catch (TACC) is the TAC less allowances. Most but not all stocks are in the QMS. As of May 2014 there are 638 stocks (from 100 species or species groupings) in the QMS. TAC setting for QMS stocks is guided by the harvest strategy standard with fishery specific objectives detailed in National Fisheries Plans (http://www.fish.govt.nz/en- 
nz/Fisheries+Planning/default.htm) consistent with overarching government fisheries policy (New Zealand Ministry of Fisheries 2009).

In Australia, the management of fisheries is shared between Commonwealth (Federal) and State governments. State fisheries management operates up to 3 nautical miles off the Australian coast, while Commonwealth fisheries management, which we focus on in this investigation, is applicable between the 3 nautical miles and the Australian EEZ boundaries. The Australian Fisheries Management Authority (AFMA) manages sixteen Commonwealth commercial fisheries, defined based on species targeted, area fished and/or gear used. Overall guidance and direction is provided by the 1991 Fisheries Management Act (Anon. 2009) and Fisheries Administration Act (Anon. 2008). The latter established AFMA at armes length from government, with its own independent Board empowered to make management decisions such as setting TACs. Oversight of AFMA"s performance does occur through the federal department of fisheries, and the minister of fisheries can over-ride AFMA Board decisions, though this occurs very rarely. There is also general oversight of fishery management performance by the federal department of environment.

\section{Science}

The main advisory body for EU fisheries management in the North-East Atlantic is ICES. ICES working groups are attended by scientists (mainly from national research institutes). The ICES advisory basis to TAC setting has historically been founded on precautionary approach (PA) reference points (ICES 1998), and provided for data-rich stocks only. Since 2009, the advice has been primarily based on MSY ( $\left.\mathrm{F}_{\mathrm{MSY}}\right)$, and there has been increasing impetus to provide additional advice for other data-limited stocks (ICES 2013). In the Mediterranean Sea, the GFCM initiates stock assessments in relation to MSY-based reference points. Finally, before formulating advice to the Council of Ministers for all waters under its jurisdiction (including the Mediterranean Sea), the European Commission is required to take advice from its own Scientific, Technical and Economics 
Committee on Fisheries (STECF), which offers additional insights in relation to stock assessments, long term management plans and other measures, binding together biological, social and economic aspects.

In Iceland, the Marine Research Institute (MRI), a government institute, provides the Ministry with scientific advice based on its research. The most extensive of the MRI activities is the systematic assessment of marine stocks and its advisory role for the management of fisheries. The stock assessment findings of the MRI are subject to review by ICES before the TAC recommendations are made.

In New Zealand, a wide panel of research providers ranging from individual scientists to research institutes such as NIWA (The National Institute of Water and Atmospheric Science), Ministry scientists and managers, industry science and other representatives, recreational and customary fisheries representatives, and occasionally environmental NGOs, participate in stock assessment working groups, review meetings and in the advice-drafting process, all of which are fully open to the public though subject to clear protocols. Stock assessments are carried out in line with relevant National Fisheries Plans and are managed by the Ministry, with work being undertaken by contracted science providers and subject to continuous and final review in the working groups and plenary meetings. Most of the commercially important stocks are considered every 2-3 years with final advice being compiled in plenary reports using standardized summary formats showing current status estimates and projections under multiple scenarios (Ministry for Primary Industries; 2014a, 2014b).

In Australia, like in New Zealand, scientific advice is provided by several research providers. For AFMA fisheries, this is dominated by the Commonwealth Scientific and Industrial Research Organization (CSIRO), but there are also important contributions made from state fishery scientists and from a number of scientific consultants. The Australian Bureau of Agricultural and Resource Economics and Sciences (ABARES) provides an annual report on stock status, summarizing much of the research and assessments undertaken. The science and assessments are presented to and 
considered by Resource Assessment Groups (RAGs) that have been established for each major fishery. The main role of RAGs is to provide advice on the status of fish stocks, and to provide the inputs needed to the formal harvest strategies for each species and stock. They also advise on monitoring and research priorities for the fishery. RAG advice goes to the management advisory committees (MACs), but also directly to the AFMA Board.

\section{Stakeholders' involvement}

In the EU, the Advisory Councils (ACs), previously known as Regional Advisory Councils, were created to strengthen, at EU level, stakeholders ${ }^{\text {ee }}$ involvement in the decision-making process. ACs are made up of representatives from the fishing sector and other interest groups affected by the CFP. Scientists can be invited as experts, while the European Commission and national administrations may participate in the ACs as active observers. The Commission may consult the ACs when developing management plans, though the process is not formalized. ACs may also inform the Commission or the Member States of problems relating to the implementation of CFP rules and formulate recommendations. Stakeholderse involvement is also materializing at the member states level through the strengthening of national industry structures, in the decision-making process, sometimes with an informal advisory function. Stakeholders ${ }^{\text {ee }}$ participation in scientific advice (e.g., ICES) exists, but it is limited compared to New Zealand and Australia. Finally, there is no EU-wide cost-recovery of government management/advisory expenditures from the fishing industry.

In Iceland, the fisheries management system is in public hands. However, the fishing industry has an indirect role to play in TAC-setting, mostly through consultation, and a more direct role in relation to the implementation of ITQ management. The industry has representatives on the board of the Marine Research Institute and also generally in official committees that handle affairs related to fisheries management, such as regarding the design and implementation of TACs. Furthermore, various industry representatives are routinely consulted by parliament in the drafting of legislation related to 
fisheries management. Finally, Icelandic fishing companies contribute financially to fisheries management expenditures through a resource tax.

In New Zealand, policies, standards and fishery plans are all developed with wide stakeholder and public consultation in prescribed processes. The Ministry of Primary Industries has separate groups dealing with operational policy and science. The Operations group deals with a range of issues, including provision of advice on regulatory controls and TAC-setting. Stock assessment outputs from processes managed by, and advice from, the Science group are a major input to the Operations group. Other inputs come in the form of managerse deliberations with commercial, recreational and customary sectors, and relevant papers on, e.g., environmental and economic matters. Finally, government expenditures (including funding of stock assessment meetings) are to a large extent costrecovered from the fishing industry via a levy derived from the annual landings value.

A key feature of Australian fisheries management is the formalized industry liaison and consultation that occurs. Strong stakeholder engagement is a feature of the AFMA management system, with fishers, environmental NGOs and scientists represented on MACs and RAGs for each fishery, and often appointed as members of the AFMA Board (Smith et al. 1999). The wide membership ensures that, in addition to scientific information on each fish stock, industry knowledge and developments in management strategies, market prices and the costs of harvesting are also taken into account. Finally, similar to Iceland and New Zealand, the Australian fishing industry contributes financially to fisheries management expenditures through a cost-recovery scheme.

\section{Management objectives and strategies}

The founding fisheries management decrees of the different jurisdictions highlight similar objectives of ecological and environmental sustainability, and also of optimizing resource utilization. These objectives have to varying degrees been translated into quantitative management targets, and a 
number of strategies have been developed to achieve them.

Regarding EU Northeast Atlantic fisheries, several management plans gradually emerged during the period 1999-2013, but these applied only to a limited number of stocks. Plans were primarily established for single stocks, and included a strict harvest control rule (HCR) building on specific target and limit reference points, these being defined with regards to population size and/or fishing mortality, and with a constraint imposed on the inter-annual TAC variation. Most of these management plans were of a "top-down" nature. In the 2013 CFP reform, MSY was officially established as the management target to be achieved for all fish stocks if possible by 2015 and at latest by 2020 (EC 2013), thus legally supporting the Johannesburg Agreement and the MSY basis of ICES advice. The 2013 CFP aims to generalize multiannual management plans to cover all stocks, but with a different approach. MSY-based regional plans should be established, covering all exploited stocks within mixed fisheries, but with more flexible and generic rules for fixing the annual TACs. In 2015, major steps have already been achieved towards designing and evaluating such regional plans, but none of them have yet been agreed at the time of writing.

In the EU Mediterranean fisheries, the CFP management objectives are the same as in other areas, and these have been explicitly included in the Mediterranean Regulation (EC) 1967/2006. However, EU fisheries have not been subject to top-down management plans as in Northeast Atlantic waters. Instead, it has been considered appropriate to promote National Management Plans (NMPs), combining effort management with specific technical measures. Italy has gained great experience in the implementation of NMPs, with examples including the towed gears NMPs enforced since 2010 for each Geographical Sub-Area, with the aim of reducing the exploitation rate for a pool of target species below a target level. NMPs targeted at specific fisheries have since 2012 been implemented in all EU Mediterranean countries. Ultimately, these plans should also be combined into a regional management plan, as for the other EU regions.

In Iceland, management objectives and principles for Icelandic fisheries have been established under 
the legal framework of the 2006 Fisheries Act. The main objective of fisheries management in Iceland is to promote conservation and efficient utilization of exploitable marine stocks, thereby ensuring stable employment and settlement throughout the country. In practice, the main emphasis has been on economic efficiency and stock sustainability through the use of ITQ systems for most fisheries. Although no explicit management targets are set in the 2006 Fisheries Act, these have been included in current management plans for some key commercial stocks, e.g., capelin, cod, saithe and haddock.

There are two outstanding features in the New Zealand Fisheries Act 1996 (Anonymous 2005): (1) the obligation that Maori interests are preserved and, (2) the explicit reference to $\mathrm{SSB}_{\mathrm{MSY}}$ as a management target. The default value for $\mathrm{SSB}_{\mathrm{MSY}}$ is assumed to be 40 per cent of the unfished spawning biomass estimated from single-species models (Mace et al. 2014). In addition, all QMS fish stocks have since 2008 been managed following Harvest Strategy Standards (HSS) operational guidelines (Mace et al. 2014). The HSS aims at achieving (MSY-based) management targets with a high probability, whilst ensuring that recruitment is not impaired, by using a soft limit (triggering requirements for a formal rebuilding plan), a hard limit (below which fisheries should be considered for closure), and formal rebuilding requirements (New Zealand Ministry of Fisheries 2008; Large et al. 2013).

An original feature of the Australian Fisheries Management Act 1991 (Anonymous 2009) is that the balance between conservation and utilization should be achieved by achieving the Maximum Economic Yield (MEY; the largest net economic return that can be achieved over a prolonged period of time while maintaining the stocks ${ }^{e e}$ productive capacity). For many Australian stocks, $\operatorname{SSB}_{\mathrm{MEY}}$ is estimated by default to be 48 per cent of the unfished biomass (Smith et al. 2008; Large et al. 2013). In addition, a formal harvest strategy policy (HSP) was adopted for all Commonwealth fisheries in 2007 (DAFF 2007; Rayns 2007; Smith et al. 2009). The HSP represents an operational framework that explicitly enables the implementation of the requirements of the Fisheries Management Act 
1991, Fisheries Administration Act 1991, and of the Environment Protection and Biodiversity Conservation Act 1999 (Smith et al. 2007). HCRs that are consistent with the HSP typically include a target biomass, a limit biomass reference point, and sometimes a target fishing mortality and a limit fishing mortality. Minimum standards have been established for the HSP reference points (Rayns 2007). Rebuilding strategies are developed for those stocks below the limit biomass, and these involve setting targeted catches to zero until the stock recovers at least to the limit reference biomass. If stock biomass drops substantially below the limit biomass, they may also be subject to a formal recovery plan issued by the Australian Minister for the Environment. An important development of the Australian HSP has been the inclusion, for several fisheries, of an even more comprehensive decision-making support framework, the tiered approach, to account for various levels of information and assessments (Smith et al 2008; Smith et al. 2009). The tiered approach provides an extra-layer of precaution to the HSP, which reflects the levels of uncertainty in stock status (each corresponding to a tier). Typically, target exploitation rates decrease as the uncertainty increases. Each Tier has its own harvest control rule that is applied to advise on TACs. Tradeoffs between the levels of catch, the levels of risk, and the monitoring and management costs are explicitly considered (Dowling et al 2013).

\section{Management tools}

Catch limits, usually referred to as TACs, are the cornerstone of the management approach to conservation in all regions being investigated, except in the Mediterranean. Effort limits and technical measures are the main management tools for EU Mediterranean fisheries, and these are also implemented to varying degrees in the other regions. Access to the fishery requires a license/permit in all jurisdictions, and an individual catch/landing entitlement for some of them.

Since 1983, the EU has gradually capped the catches of most commercially important stocks with TACs in the Northeast Atlantic. The fundamental principle of the CFP is that member states can fish 
any stock in all EU waters, provided they have a quota provision for that stock. The EU does not vest authority to allocate national catch quotas to individual producers or vessel owners. However, rightsbased management has been increasingly implemented under the authority of individual EU member states (Larabi et al. 2013; Aranda and Murillas 2015; Le Floc ${ }^{\text {h }}$ et al. 2015), including a formal ITQ system in The Netherlands and Denmark. Direct effort limitations have also been implemented instead of (Mediterranean), or in complement to (Northeast Atlantic) TACs. In the Mediterranean, fishing effort limitations have been the most important component of fishery management (Pearce, 1980; Catanzano et al. 2000). Technical measures have been implemented in most EU fisheries: Minimum Landing Sizes (MLS), gear restrictions and closed areas/seasons. In the North East Atlantic, the ranges of minimum mesh sizes (e.g. 70-120 $\mathrm{mm}$ for demersal otter-trawlers) is higher than that operated in the Mediterranean (e.g., 20-40 $\mathrm{mm}$ for trawlers). Public-aided fleet capacity reduction schemes have also been an important conservation instrument of the CFP in both the Northeast Atlantic and the Mediterranean (Guyader et al. 2007; Quillerou et al. 2013; Aranda and Murillas 2015).

The main feature of fisheries management in Iceland is its ITQ system (Arnason 1995). All major commercial stocks are now subject to ITQs, except for specific coastal fisheries. Every year, the Directorate of Fisheries calculates and issues an annual catch quota $(\mathrm{kg})$ to individual vessels, by multiplying the total TAC with the vessels ${ }^{\text {ee }}$ quota share (\%). Under certain circumstances, it is permitted to transfer both quota shares and annual catch quotas between vessels. There are specific limits to quota concentration. These limits apply to both individual species quota shares as well as total quota share cumulated over all species. The restrictions stipulate in particular that vessels may not purchase quotas (or may even lose their permanent quota shares) when these are clearly exceeding their catch capacity, and also that the quota-shares held by any company or individual should not exceed certain limits. There is some additional flexibility built into the ITQ system including, (1) a carryover of $20 \%$ of catch quota to the following fishing year, (2) a permission to 
land up to $5 \%$ over-quota subject to conditions, (3) the possibility to transfer catch quotas between demersal species and, (4) the possibility to withdraw only a part of juvenile fish catches from quotas. In addition to TACs and ITQs, discarding is prohibited and technical measures are implemented. These include a Minimum Catch Size (MCS) for most stocks, a minimum mesh size (e.g., 135-155 $\mathrm{mm}$ for demersal trawlers), and extensive provisions for temporary closure of fishing areas to protect spawning or immature fish (ICES 2013).

The major feature of New Zealand fisheries management is its freely tradable ITQ system and the way it generates Annual Catch Entitlement (ACE) which is used to balance catches (Squires 2010; Mace et al. 2014). Unlike in Iceland, fishers do not need to own ITQ and ITQ is not linked to vessels. The TACCs of all QMS stocks are distributed to quota holders as ITQ shares. On the first day of the fishing year, each ITQ (expressed as a percentage of the TACC) generates for each quota holder, and each stock, an amount of ACE, in $\mathrm{kg}$. ACE and ITQ are freely tradable on the open market and accessible to any New Zealand citizen. One aspect of quota concentration requirements in New Zealand is that a minimum 20 per cent share of any new QMS species has been allotted to Maori since the inception of the Fisheries Settlement. All fish and shellfish must generally be landed in New Zealand, so discarding cannot be seen as an option to balance landings with ACEs. Different procedures have been adopted to bring in more flexibility in catch-quota balancing. If there is a mismatch between catch and ACE purchased, fishers are required to pay an interim deemed value, for each unit of catch they land above their ACE holdings at the time, with a final deemed value reckoning at the end of year (Marchal et al. 2009). The deemed value is reviewed annually, like the TAC and the TACC, to reflect fluctuations in fish port and quota prices (Mace et al. 2014). ACEholders are also allowed to carry forward up to $10 \%$ of their ACE to the following fishing year. That carry-forward is lost entirely if the TACC is reduced. Finally, direct effort limits and technical measures are only applied in specific small-scale fisheries.

While the changes to fishery management implemented in Australia in the early 1990s put a strong 
focus on use of TACs coupled with ITQs, few fisheries are managed purely using output controls. A range of input controls are used including use of statutory fishing rights, limited entry, gear restrictions, and spatial management. Discarding is generally tolerated in Australia (Sanchirico et al. 2006). Buyback schemes have been implemented in several fisheries to adjust capacity to resources (Fox et al. 2006; Fox et al. 2007; Minnegal and Dwyer 2008). A major buyback scheme was implemented in conjunction with the adoption of the harvest strategy policy in 2007. Formal methods of management strategy evaluation have been used to assess the impacts of alternative sets of measures aimed to meet a variety of management goals (Fulton et al. 2014) including fisheries with strong traditional and indigenous components (Plaganyi et al. 2013). Access rights in Australia are generally similar to those in New Zealand, based around statutory fishing rights and in some fisheries allocation of individual transferable quotas (Smith and Smith 2001). Increased use of spatial management for conservation purposes and adoption of a large network of marine protected areas have eroded some of these rights in the view of many fishers. Sharing resources between state and federal jurisdictions is an issue for some stocks.

\section{Management performances}

\section{Conservation}

We compared the conservation performances of the different management systems under investigation by considering, wherever possible, three criteria: (i) the status of fish stocks, (ii) how TAC setting is in line with scientific advice and, (iii) how well are TACs adhered to.

\section{Fish stocks status}

Comparing the status of fish stocks across the world is not trivial. This is because the range and frequency of stock assessments, as well as reference points, are not necessarily consistent across management and advisory agencies. For the purpose of this exercise, we have collated and summarized the recent status of the different stocks assessed in the Northeast Atlantic, Mediterranean 
Sea, New Zealand and Australian waters, using fishing mortality and biomass limit reference points. Although limit reference points generally differ within and across jurisdictions, they all represent thresholds which, if exceeded, should trigger appropriate management action. For the EU Northeast Atlantic and Icelandic stocks evaluated by ICES, the limit reference points were taken as $\mathrm{F}_{\mathrm{pa}}$ and $\mathrm{B}_{\mathrm{pa}}$, building on the precautionary approach framework. For Mediterranean Sea, only F-based limit reference points are generally considered, with a usual reference set to $\mathrm{F}_{0.1}$ (as a proxy for $\mathrm{F}_{\mathrm{MSY}}$ ). For New Zealand fisheries, the limit reference points were taken as the soft limit. For Australian fisheries, the limit reference points were associated to a risk of recruitment impairment.

We used stock status information assessed against limit reference points for the Northeast Atlantic, including EU and Icelandic stocks (ICES 2004; ICES 2005; ICES 2006; ICES 2007; ICES 2008; ICES 2009; ICES 2010; ICES 2011; ICES 2012; ICES 2013), the Mediterranean Sea (STECF 2013a; STECF 2014a), New Zealand (New Zealand Ministry of Primary Industries 2013) and Australian stocks. Two sources of information could be considered regarding Australian fisheries: one focusing on the federally managed stocks with fisheries status information available over the period 20042012 (Woodhams et al. 2013), and the other one focusing on all Australian stocks in year 2012 (Flood et al. 2012). Another difference between the two stock status reports is that they use somewhat different criteria for judging overfishing. We considered here stock status information provided in Woodharms et al. (2013), since our study focuses on federally managed fisheries, and also since this report allowed comparing stock statuses across periods (2004-2012).

Table 3 provides recent stock statuses in 2013 (EU, Iceland, New Zealand) and 2012 (Australia). It can be seen that the number of stocks for which scientists evaluate SSB or F against limit reference points is higher in Australia and New Zealand than in the other areas. This statement, however, does not prejudge the relative precision of the stock assessments being carried out in the different world regions. The figures provided for Icelandic stocks are purely indicative and are not considered in subsequent analyses, due to the relatively low number of stocks for which stock status is informed 
quantitatively (3-5). Note that none of the Icelandic stocks were harvested beyond limit reference points. The proportion of stocks where $\mathrm{SSB}$ is above $\mathrm{SSB}_{\lim }$ is slightly higher in New Zealand and Australia (82-88\%) than in the EU Northeast Atlantic (71\%), but the difference is not significant. Also, the proportion of stocks where $\mathrm{F}$ is below $\mathrm{F}_{\text {lim }}$ is higher in New Zealand and Australia (8295\%) than in the EU Northeast Atlantic (68\%), and even more so compared to the Mediterranean Sea stocks (8\%). The differences (with or without Mediterranean stocks) have been tested using a ChiSquare test and are significant $(\mathrm{p}<0.01$ or $\mathrm{p}<0.001)$.

Figure 1 shows how fishery statuses have changed since 1984 (EU and Australian stocks) and since 2009 (New Zealand). The proportions of stocks above $\mathrm{B}_{\text {lim }}$ and below $\mathrm{F}_{\text {lim }}$ have overall increased over time, and these have consistently been higher for Australian and New Zealand fisheries compared to the EU fisheries. However, when one considers biomass levels, the gap has been reduced since 2011, and the difference is currently not significant (Table 3).

\section{TAC and scientific advice}

All fisheries resources investigated in this study are primarily regulated by TACs, except in the Mediterranean. The degree to which TACs adhere to the long term catch options recommended by fisheries scientists is variable across the different jurisdictions.

In New Zealand, TAC and TACC setting for all stocks is requested by law to be consistent with remaining above, or rebuilding to, $\mathrm{B}_{\mathrm{MSY}}$. For a number of stocks, TACs/TACCs have been managed consistent to a biomass level well above $\mathrm{B}_{\mathrm{MSY}}$. For instance, hoki, one of the most important fisheries resources in New Zealand has $\mathrm{B}_{\mathrm{MSY}}$ circa $27 \% \mathrm{~B}_{0}$ but is managed to be in a 35 $50 \% \mathrm{~B}_{0}$ target range. The Harvest Strategy Standard framework also requires that any TACs set for rebuilding purposes have to enable a return to $\mathrm{B}_{\mathrm{MSY}}$ with a probability of $70 \%$ within a specified time frame. In Australia, TACs for all stocks are derived directly from the appropriate HSP ${ }^{\text {ee }}$ harvest control rules. TACs may occasionally be lower, but never higher than the advised catch. 
Such explicit legally-binding requirements tying together agreed TACs and advised catch levels do not exist as explicitly in the EU and Iceland fisheries policies, except when stocks are subject to a management plan. For EU Northeast Atlantic and Icelandic stocks, we compared advised catch and agreed TACs over recent years (2010-2013) based on ICES (2014). For EU Northeast Atlantic stock, the information used in Marchal et al. (2009) to compare TACs and advised catches over the period 2002-2006 was also extracted in the same format to allow comparisons with the 2010-2013 period. In Table 4 and Figures 2a,c, we compare the proportions of cases (i.e., combinations of stocks and years) for which the agreed TAC exceeds advised catch, between periods (2002-2006 versus 2010-2013) for EU Northeast Atlantic fisheries, and between regions (EU Northeast Atlantic versus Iceland) for period 2010-2013. Although the frequency of EU TACs set above advice is still high $(59 \%)$ in $2010-2013$, it has significantly $(\mathrm{p}<0.05)$ decreased since 2002-2006 (67\%). The frequency of TACs above advice is not significantly different between EU Northeast Atlantic and Icelandic stocks.

\section{Catch limits and actual catches}

We investigated here how efficiently catch limits constrain landings across the different regions. For EU, Icelandic and Australian stocks, catch limits were represented by the TAC and compared to total annual landings. For New Zealand stocks, the ACE (derived from TACC through ITQ) is the primary, annual currency for management. Compared to the TACC, the ACE better portrays the constraint exerted on fishers, and it was here considered as the appropriate catch limit metric with regards to New Zealand stocks.

In Table 5 and Figure 2b,d, we compared the frequency of realized catches above TAC (or, for New Zealand stocks, the frequency of individual catches above ACE). Because limited carryovers are allowed in Iceland, Australia and New Zealand, we also compared in Table 5 the frequency of catches above the limit plus $10 \%$. 
The frequency of realized catches above the limit is higher for Icelandic stocks (57\%) compared to EU Northeast Atlantic stocks (27\%), but the frequency of catch realization versus catch limit plus $10 \%$ is slightly higher for EU stocks (18\%) compared to Icelandic stocks (12\%). This could reflect that limited over-quota catches are more frequent in Iceland than in the EU (possibly due to the Icelandic carry-over allowance), but also that larger-scale over-quotas catches are more frequent in EU waters than in Icelandic waters. The frequency of over-quota catches is much lower $(\mathrm{p}<$ 0.001) for Australian and New Zealand stocks (3-6\%) compared to EU and Icelandic stocks (3457\%). Australian and New Zealand catches almost never exceed the catch limit plus 10\% threshold, which again may illustrate the limited carry-over authorized in these countries.

\section{Economics}

Economic efficiency may be gauged by considering the criterion of average amount of government financial transfers (GFT), which could be made available across the four case studies (Table 1). The GFT figures should, however, be interpreted cautiously as information reported was occasionally missing or inconsistent (OECD 2013). GFT represented 14-15\% of the total landing value in the EU (with considerable disparities across EU member states, due to different political attitudes towards subsidies) and New Zealand, and only $2-3 \%$ in Iceland and Australia. A key difference between EU and New Zealand is that subsidies (direct payments and cost-reducing transfers) represent about 50\% of the EU GFT, while the totality of New Zealand GFT covers general services including management, research and enforcement. Another essential economic performance indication is that $36-65 \%$ of GFT are cost-recovered from the industry in Australia, New Zealand and Iceland, while they are supported by tax-payers in the EU. Both the fleet size and the number of fishers employed on-board EU vessels have declined considerably since the mid-nineties (STECF 2013b). These decreasing trends are still notable in more recent years, where both the size of the EU fishing fleet and the number of fishers it employs have reduced by $2 \%$ and $3 \%$ respectively (Table 1 ). The size of 
the New Zealand fishing fleet has remained stable, while employment in the harvest sector has slightly declined (by 2\%) over recent years. The size of the Australian Commonwealth fishing fleet and the number of fishers have reduced by $1 \%$ and $5 \%$, respectively. In contrast, the Icelandic fishing fleet size and employment in the harvesting sector have gradually increased (by $2 \%$ and $21 \%$ respectively) in recent years.

\section{Conclusions}

Comparing the respective strengths and weaknesses of fisheries management in countries of similar levels of development such as the EU, New Zealand, Australia, and Iceland is an instructive exercise (Table 2). New Zealand, Australia and Iceland have paved the way of modern fisheries management in many respects. It is important to note, however, that other countries, e.g., Norway, USA, Canada, South Africa, have also been at the forefront of implementing innovative fisheries management. Examples of innovative management features in these countries include the management of catchquota balancing by full observer and/or closed circuit television on-board fishing vessels in some Canadian ITQ fisheries (Branch et al. 2006), or the spatial management of by-catch and discards in various US fisheries (Little et al. 2014), which could in future investigations be considered to broaden the scope of this comparative review.

Australia and New Zealand have been at the forefront of incorporating stakeholder involvement at all levels of the decision-making and science process, including funding via cost recovery levies. Thus, the cost recovery system does incentivise engagement in parts of the science planning and stock assessment processes. The EU has more recently taken significant steps to better organise the stakeholders $^{\text {ee }}$ consultation process by promoting ACs. Although the role of the ACs in the decisionmaking process is still limited, there are examples where they have been influential, particularly in relation to pelagic fisheries. EU stakeholderse involvement, however, does not go as far as funding fisheries management and research. A cost recovery system such as that operated in Australia and 
New Zealand may provide advantages for stakeholder engagement in science and management, and it could also be attractive to some EU member states, the social policy of which makes them reluctant to fund fisheries management and research with public money. Indeed, we showed that the amount of GFT (expressed as a proportion of landings value) was substantially lower in Iceland, New Zealand and Australia compared to the EU. There are, however, important downsides to implementing a cost recovery system at EU level (Karagiannakos 1996; Motos and Wilson 2006). For instance, the amount of funding available for science to support decision-making processes requiring technical input could be more limited than in a fully public-funded scheme, especially when landings and/or fish prices are low. The complexity of certain steps in the scientific process in EU fisheries, as for example the data collection and integration (Gascuel et al. 2012), particularly for non-targeted species, makes it more demanding in funding than in single-nation fisheries, thus making it difficult to cover by cost recovery alone. In addition, applying a cost recovery system requires solving core questions such as how levies would be applied to fishers and/or quota holders (Motos and Wilson 2006), which in the EU supra-national context could be a thorny issue.

For over two decades, New Zealand and Australia have had explicit legally-binding fisheries management targets in their founding decrees. To achieve these targets, New Zealand and Australian authorities adopted management strategies applicable to almost all fisheries resources, including data-limited species (DLS) (Dowling et al 2014). This approach to comprehensive and objectivebased management has generally brought TAC-setting equal or close to scientific advice in these countries. In the EU and in Iceland, the lack of quantitative management objectives, until recently, for those fisheries not subject to a management plan often resulted in TACs being set above advised catches. The deviation between TAC setting and scientific advice has also likely been nurtured, in Iceland, by quota carry-over allowances, and in the EU, by the complexity of regulations and differing socio-economic interests between member states. We also showed, however, that the development of management plans for several key stocks has alleviated the discrepancy between EU 
TACs and ICES advice in the North-East Atlantic. Following the 2013 CFP Reform, the gradual establishment of MSY as a management target for all fish stocks (including DLS) may potentially render EU TAC decision-making increasingly consistent with scientific advice. It is also worth noting that ICES is now providing advice for most commercial fish stocks in the Northeast Atlantic, thereby providing a scientific rationale to support the application of future EU management plans to a broader range of fisheries. The situation in the Mediterranean, however, is more difficult and progress less clear (Smith and Garcia 2014; Vasilakopoulos et al. 2014). The EU is showing increasing concerns about Mediterranean stocks, and the Commission has in several occasions expressed the view that the recovery of Mediterranean stocks should now be regarded with the highest priority (EC 2015).

Minimum mesh sizes are generally larger in Iceland, compared to the EU Northeast Atlantic fisheries, and even more so compared to the EU Mediterranean fisheries. While the larger mesh size used in Iceland allows catching older fish, it is also important to note that for the same species, the age/size at maturity is substantially lower in EU waters. This is also reflected by larger minimum catch/landing sizes in Icelandic Seas in comparison to EU waters (ICES 2015a; ICES 2015b). Considering cod as an example, studies carried out in the Baltic Sea and the North Sea suggest that the L50 (length at half retention) range obtained with current mesh sizes and gear configurations used by trawlers is generally above MLS except when they target other species than cod (Graham et al. 2004; Graham et al. 2007; Madsen 2007). Although we were not aware of recent selectivity studies focused on Icelandic cod, experiments carried out in the Barents Sea (i.e., at a comparable latitude to Icelandic waters) suggest that the L50 obtained with the current range of trawl mesh sizes used in Iceland is larger than the MCS when targeting cod, but not when targeting redfish (Sistiaga et al. 2011). These results suggest that current mesh sizes used by Icelandic and EU Northeast Atlantic trawl fisheries are reasonably consistent with prevailing MCS/MLS regulations when targeting cod, but not when targeting other species. This is perhaps not a major issue for the directed Icelandic cod 
fisheries, but it is an important one for complex EU trawl fisheries catching a variety of species of different life-history characteristics (Marchal and Horwood 1996).

Attitudes towards discarding also differ across the different case studies, with a ban in New Zealand, Iceland, and some tolerance in the EU and Australia. However, it is difficult to evaluate the extent to which these diverging discard policies contributed to the contrasted management performances found in the different regions under investigation. In the EU Northeast Atlantic, the lack of discard time series has for a long time hampered the assessment accuracy of several fish stocks, and thereby the main scientific source for TAC-setting (Viana et al. 2011). The situation has improved since 2002 with the implementation of systematic discard sampling on-board fishing fleets, and some discards estimates are now available for almost all stocks (ICES 2013). A binding landing obligation is gradually coming into force in the EU over 2015-2019 (EC 2013). It remains to be seen whether and how the EU landing obligation will affect the precision of stock assessments and, more generally, the performances of the fisheries management system.

Closed areas have been implemented in the different regions being investigated. It is, however, difficult to evaluate how successful such measures have been in achieving conservation benefits. In the North Sea, reviews of the "Plaice Box" conservation performances have suggested limited success (Beare et al. 2013). In Iceland, a preliminary evaluation of real-time closures suggests limited effects on juveniles ${ }^{\text {ee }}$ protection. While larger areas closed for a longer time period could force vessels fishing in other areas, their effects have not been evaluated (ICES 2013).

Considering access regulation, New Zealand and Iceland have been pioneers in implementing a generalized ITQ system to regulate access to their fisheries. Regulating fisheries by means of ITQs provides a cost-efficient way to reduce fleet overcapacity and improve economic results (Mace et al. 2014). Since the inception of the ITQ system, the productivity of the Icelandic and New Zealand fishing industries has increased substantially (Clark and Major 1988; Dewees 1988; Annala 1996; Agnarsson 2011; Arnason 2003). The New Zealand ITQ system is more flexible than the Icelandic 
one, as any New Zealand citizen may acquire ITQ or ACE while in Iceland, quota ownership is restricted to vessel owners. ITQs are not fully market-driven, either in New Zealand or Iceland, where a combination of quota concentration limits and/or fixed quota share allocations have been imposed to safeguard the fishing opportunities of specific communities, although the extent to which this has been achieved is subject to debate (Eythorsson 2000; Benediktsson and Karlsdottir 2013). The EU has not vested authority to allocate quotas to individual fishers, and only some member states have formally or informally adopted IQ or ITQs for some of their fisheries.

Overall, the management of domestic fisheries in Australia and New Zealand has performed better than in the EU, in terms of bringing fishing mortalities below limit reference points. However, considering the proportion of stocks above limit biomass, we also showed that the gap has been substantially reduced between the EU and the other jurisdictions. Although it was not possible to test the differences between EU and Icelandic stocks conservation status, due to the limited number of Icelandic stocks being considered, it is perhaps noteworthy that none of the Icelandic stocks were harvested beyond limit reference points. It is, however, important to keep in mind that our analysis did not consider highly migratory species and/or straddling stocks not subject to a management agreement, as commented below. In the EU, the lack of management objectives, enforcement and stakeholder involvement in decision-making have repeatedly been pointed out as a likely cause for poor stock recovery (Holden 1994; Sissenwine and Symes 2007; Cardinale and Svedang 2008; O'Leary 2011; Da Rocha et al. 2012; Santiago et al. 2015). Yet, we could also show in this study that the overall status of EU Northeast Atlantic fish stocks has substantially improved over the period 2004-2013 (Table 3), and also that TAC setting is becoming increasingly in line with scientific advice (Table 4, Figures 1 and 2). Our results also confirm that the pressure exerted by EU Northeast Atlantic fisheries has decreased in the past ten years, as a result of increasingly effective management (Cardinale et al. 2011; Cardinale et al 2013; Fernandes and Cook 2013), although intended fishing mortality reductions have likely been limited by adaptive fleets ${ }^{\text {ee }}$ responses (Hatcher 2000; Lindebo 
2005; Marchal et al. 2007; STECF 2014b). Biomass recovery, however, has been slow and recruitment has been poor in many cases (Gascuel et al. 2014). It is also important to stress that the CFP, which has assisted in improving the state of EU Northeast Atlantic fish stocks over the past ten years, has failed to deliver similar results for Mediterranean fisheries (Smith 2013; Smith and Garcia 2014). In this region, efficient conservation action has in particular been strained because the jurisdiction of coastal states is generally limited to 6-12 miles (200 miles in the Northeast Atlantic), and because GFCM recommendations have only been binding for EU member states. Limiting juvenile exploitation, advancing management plans and strengthening compliance, control and enforcement could promote fisheries sustainability in the Mediterranean (Vasilakopoulos et al. 2014). STECF (2013c) also suggests that the economic performance of EU fishing fleets operating in the Mediterranean has generally deteriorated compared to those fishing in the Northeast Atlantic.

The implementation of ITQs in New Zealand and Iceland has resulted in a rationalisation of the fleets. The EU fleet capacity was also subject to substantial reductions, but these were often slower and incentivized by public subsidies, and not market-driven. It is, however, fair to mention that, compared to New Zealand and Iceland, overcapacity was probably more of an issue in the EU at the start of (CFP-driven) management actions, thereby providing an additional challenge (Mace et al. 2014). After World War 2 most European countries were financially stressed, so governments wanted to secure large volumes of food supplies to feed their populations, and fish were an obvious source. There were no fears of overproduction, as experts were forecasting at that time a world shortage of food (Holden 1994). For these reasons, fishing capacity investments were encouraged and subsidized (FAO 1988; Holden 1994). Much of the new capacity was deployed in distant waters such as Canada, and Iceland. It meant that when EEZs were declared in the 1970s that capacity was redeployed in EU waters with an inevitable excessive pressure on fish stocks ultimately reducing some of them to a very poor state. Conversely, overcapacity in Icelandic waters was alleviated with the removal of EU fleets so by 1983, Icelandic stocks were probably in a better shape than EU stocks. Similarly, in 
Australia and New Zealand, most of the foreign fleets moved outside the new EEZ boundaries, resulting in a decrease in fishing pressure by 1983.

It should also be stressed that managing the fisheries of 28 countries with varying interests, economic structures and political traditions, as the EU does, is more complex than managing fisheries in one sovereign country, where decisions are made by one single Minister, as is the case in Australia, New Zealand and Iceland. This is highlighted during negotiations of accession of new member states, or through contentions stemmed by the application of the relative stability principle (Churchill and Owen 2010). The EU provides mechanisms for management agreement between countries sharing straddling stocks, which is in effect an additional layer of governance on sovereign states that is not required by IC-AU-NZ, and is perhaps also a clue to the disparity in management performance. ICAU-NZ share certain stocks with other countries, the management of which is generally implemented by RFMOs or through multi-lateral agreements. There are, however, cases where no agreement can be found. For instance, Northeast Atlantic mackerel was until 2008 managed by a multilateral agreement involving the EU, Iceland, the Faroe Islands and Norway. Failure to agree on common standards has impeded the development of management plans since 2009 , resulting in some countries declaring their own TAC without agreement with other partners. Such examples suggest that the EU system, despite all its imperfections, has been progressive in developing legally-binding management measures, with common enforcement standards, on stocks shared by sovereign nations.

Since the inception of the 2013 CFP, the EU has strengthened its management objectives (gradual establishment of MSY to all fish stocks) and conservation measures (gradual implementation of discard limitations), raising better prospects for the future sustainability of its fisheries. The EU has also considered the difficulties of balancing catches with single-species TACs in mixed fisheries (Laurec et al. 1991; Vinther et al. 2004; Ulrich et al. 2011). ICES has accompanied this new management requirement by providing mixed fisheries advice in the North Sea (ICES 2013), which may inform the future regional multiannual plans. Finally, similar to many countries in the world, 
including those considered in this study, the EU has pursued significant steps towards the implementation of an ecosystem approach to fisheries by incepting a Marine Strategy Framework Directive (MSFD) (EC 2008). The future of EU fisheries management is in fact intrinsically linked with the setting of a cross-sectorial European Maritime Policy, building on the existing MSFD, the purpose of which will be to deal with the cumulative impact of human activities (including fisheries but also maritime transport, coastal tourism, aquaculture, minerals exploitation, and sea-based energy production) on the oceans, in a global change context. This cross-sectorial management approach challenges the current EU governance framework of maritime affairs, which has tended to look at maritime activities separately until now.

In our review, we have not considered how compliance and enforcement were implemented in the different regions. Superficially, the enforcement instruments are essentially similar in the four regions: monitoring is carried out through catch and effort logbooks, independent government and/or scientist observers and VMS (Vessel Monitoring System). New Zealand and Australia have also introduced participative approaches to compliance. In New Zealand, this has materialized by selfmonitoring in several fisheries (Starr, 2000). Australia has developed a National Fisheries Compliance Strategy that outlines the objectives that Australian fisheries agencies will pursue to promote voluntary compliance and create effective deterrence to illegal fishing activities. Similar initiatives are also increasingly developing on a trial basis in the EU. Comparing compliance across regions worldwide could be carried out by considering rates of infringement and standards of enforcement.

Finally, we have compared the performances of fisheries management in the EU and in IC-NZ-AU based on quantitative conservation and economic criteria. The social performances of fisheries management systems are equally important, but could not be covered in this study. This is mainly because at EU level, social policy is by large a responsibility of the individual member states, and also due to the difficulties to find standard indicators comparable across regions. One important 
aspect is how the different fisheries management systems make provision for safeguarding the interests of targeted communities. In the EU, different programs have been launched aiming at revitalizing fisheries-dependent areas. Examples of this are the Financial Instrument for Fisheries Guidance (FIFG, 1994-2006), the European Fisheries Fund (EFF, 2007-2013) or the new European Maritime and Fisheries Fund (EMFF, 2014-2020), with a stronger emphasis on small-scale fisheries and community-lead initiatives. In New Zealand, the 1992 Fisheries Claims Settlement secured Maori $20 \%$ of the quota of any new QMS species and $50 \%$ of the shares of Sealord, the most important fishing company at that time (Hersoug 2002; Johnson and Haworth 2004; Yandle and Dewees 2008). In Iceland, the Fisheries Management Act was revised in 2009 to support the interests of smaller coastal communities, by introducing a specific derby-style coastal fishery. This legislation was introduced mainly as a response to political pressures based on perceived negative social effects of the ITQ system, mainly fleet rationalization and regional issues. In Australia, Torres Strait fisheries are managed in accordance with the Torres Strait Treaty signed by Australia and Papua New Guinea. Since 1989, all non-indigenous participation in Torres Strait fisheries has been capped to protect aboriginal fishing activities. Future work could then compare the extent to which the conservation and economic performances of the different systems are related to the inclusion of coastal communities in fisheries policies.

\section{Acknowledgements}

The research leading to these results has received funding from the European Union Seventh Framework Programme (FP 7/2007-2013) under grant agreement No. 289192. The paper also greatly benefitted from the thorough and thoughtful comments of four anonymous referees.

\section{References}


Agnarsson, S. (2011) Framleiðni í fiskveiðum 1973-2008. Erindi flutt á málpingi áhugamanna um sjávarútvegsmál $15.3 \quad$ 2011. http://kvotakerfid.is/is/sidur/kvotakerfi-og-landsbyggdhagkvaemni-byggdi. [In Icelandic.]

Annala, J.H. (1996) New Zealand's ITQ system: have the first eight years been a success or a failure? Reviews in Fish Biology and Fisheries 6, 43-62.

Anonymous (2005) New Zealand Fisheries Legislation. Fisheries Act 1996, 7th edn, Vol. A. Chapmann Tripp, Barristers \& Solicitors, New Zealand.

Anonymous (2008) Australian Fisheries Administration Act 1991. Act No. 161 of 1991 as amended, taking into account amendments up to Act No. 36 of 2008, Office of Legislative Drafting and Publishing, Attorney-Generale ${ }^{\text {ee }}$ Department, Canberra, 69 pp.

Anonymous (2009) Australian Fisheries Management Act 1991. Act No. 162 of 1991 as amended, taking into account amendments up to Act No. 33 of 2009, Office of Legislative Drafting and Publishing, Attorney-General "es Department, Canberra, 407 pp.

Aranda, M., and Murillas, A. (2015) Allocation of fishing possibilities, incentives and outcomes: Insights from Basque fishermen's organizations in Spain. Marine Policy 61, 171-178.

Arnason, R. (1995) The Icelandic Fisheries: Evolution and management of a fishing industry. Oxford: Fishing News Books.

Arnason, R. (2003) On Productivity and Productivity Growth in the Icelandic Fisheries. In (E. Guðmundsson and H.P. Valtýsson (eds.) Competitiveness within the Global Fisheries. University of Akureyri.

Beare, D., Rijnsdorp, A.D., Blaesberg, M. et al. (2013) Evaluating the effect of fishery closures: Lessons learnt from the Plaice Box. Journal of Sea Research 84, 49-60.

Benediktsson, K., and Karlsdottir, A. (2011) Iceland crisis and regional development - Thanks for all 
the fish? European Urban and Regional Studies 18, 228-235.

Branch, T.A., Rutherford, K., and Hilborn, R. (2006) Replacing trip limits with individual transferable quotas: implications for discarding. Marine Policy 30, 281-292.

Cardinale, M., Dörner, H., Abella, A. et al. (2013) Rebuilding EU fish stocks and fisheries, a process under way? Marine Policy 39, 43-52.

Cardinale, M., Dörner, H., Casey, J. et al. (2011) Fishery reform: many stocks secure. Nature 476, p. 282.

Cardinale, M., and Svedang, H. (2008) Mismanagement of fisheries: Policy or science? Fisheries Research 93, 244-247.

Catanzano, J., Cunningham, S., and Rey, H. (2000) Fishery Management in the Mediterranean: An Evaluation of French Effort-based Management Systems, IIFET Biannual Conference Proceedings, Corvallis, Oregon, USA, 6 pp.

Churchill, R., and Owen, D. (2010) The EC Common Fisheries Policy. Oxford European Union Law Library, 640 pp.

Clark, I.N., and Major, P.J. (1988) Development and Implementation of New Zealand,,s ITQ Management System. Marine Resource Economics 5, 325-349.

Cueff, J.C. (2007) A case study of fishing vessel capacity management public buy-out schemes: community experience through the multi-annual guidance programmes and ways forward. Chapter 5. In: Fisheries Buybacks (eds R. Curtis and D. Squires). Wiley-Blackwell, Ames, IA., 75-80.

DAFF (2007) Australian Government Department of Agriculture, Fisheries and Forestry Commonwealth fisheries harvest strategy: Policy and guidelines. Canberra: DAFF.

Da Rocha, J.M., Cerviño, S., and Villasante, S. (2012) The Common Fisheries Policy: an 
enforcement problem. Marine Policy 36, 1306-1314.

Dewees, C.M. (1998) Effects of Individual Quota Systems on New Zealand and British Columbia Fisheries. Ecological Applications 8, S133-S138.

Dowling, N.A., Dichmont, C.M., Venables, W., et al. (2013) From low to high value fisheries: is it possible to quantify the tradeoff between management cost, risk and catch? Marine Policy $40,41-52$

Dowling, N.A., Dichmont, C.M., Haddon, M., D.C. Smith, A.D.M. Smith and K. Sainsbury (2014) Guidelines for developing formal harvest strategies for data-poor species and fisheries. Fisheries Research, in press.

EC (2003) Commission regulation (EC) No 1438/2003 of 12 August 2003: laying down implementing rules on the Community Fleet Policy as defined in Chapter III of Council Regulation (EC) No 2371/2002, Official Journal of the European Union L 204/21.

EC (2008) Directive 2008/56/EC of the European Parliament and of the Council of 17 June 2008 establishing a framework for community action in the field of marine environmental policy (Marine Strategy Framework Directive).

EC (2013) Regulation (EU) No 1380/2013 of the European Parliament and of the Council of 11 December 2013 on the Common Fisheries Policy, amending Council Regulations (EC) No 2371/2002 and (EC) No 639/2004 and Council Decision 2004/585/EC.

EC (2015) Consultation on the fishing opportunities for 2016 under the Common Fisheries Policy. $\operatorname{COM}(2015) 239$ final.

EUROSTAT (2013) Eurostat Pocketbooks: Agriculture, forestry and fishery statistics, 2013 edition. Luxemburg: Publications Office of the European Union, 249 pp.

Eythorsson, E. (2000) A decade of ITQ-management in Icelandic fisheries: consolidation without 
consensus. Marine Policy 24, 483-492.

FAO (1988) World agriculture: toward 2000. Ed. Nikos Alexandratos. Belhaven Press (a division of Pinter Publishers) London, 338 pp.

FAO (2012) FAO year book. 2010 Fishery and Aquaculture Statistics, Capture production.

Fernandes, P.G., and Cook, R.M. (2013) Reversal of fish stock decline in the North East Atlantic. Current Biology 23, 1-6.

Flood, M., Stobutzki, I., Andrews, J. et al. [eds] (2012) Status of key Australian fish stocks reports 2012, Fisheries Research and Development Corporation, Canberra.

Fox, K., Grafton, Q., Kompas, T. et al. (2006) Capacity Reduction, Quota Trading and Productivity: The Case of a Fishery. Australian Journal of Agricultural and Resource Economics 50, 189206.

Fox, K., Grafton, Q., Kompas, T., et al. (2007) Capacity reduction and productivity: a case study of the Australian south east trawl fishery. Chapter 4. In: Fisheries Buybacks (eds R. Curtis and D. Squires). Wiley-Blackwell, Ames, IA., pp. 67-74.

Fulton, E.A., Smith, A.D.M., Smith, D.C., et al. (2014) An integrated approach is needed for ecosystem based fisheries management: insights from ecosystem-level management strategy evaluation. PLoS ONE 9, e84242.

Gascuel, D., Coll, M., Fox, C., et al. (2014) Fishing impact and environmental status in European seas: a diagnosis from stock assessments and ecosystem indicators. Fish and Fisheries, DOI: 10.1111/faf.12090.

Gascuel, D., Merino, G., Döring, R., et al. (2012) Towards the implementation of an integrated ecosystem fleet-based management of European fisheries. Marine Policy 36, 1022-1032.

Graham, N., Ferro, R.S.T., Karp, W.A., and MacMullen, P. (2007) Fishing practice, gear design, and 
the ecosystem approach - three case studies demonstrating the effect of management strategy on gear selectivity and discards. ICES Journal of Marine Science 64, 744-750.

Graham, N., O'Neill, F.G., Fryer, R.J., Galbraith, R.D., and Myklebust, A. (2004) Selectivity of a $120 \mathrm{~mm}$ diamond cod-end and the effect of inserting a rigid grid or a square mesh panel. Fisheries Research 67, 151-161.

Guyader, O., Berthou, P., and Daurès, F. (2007) Decommissioning schemes and Capacity Adjustment: a preliminary analysis of the French experience. in Curtis, R. and Squires, D (ed) Fisheries Buyback, Blackwell Publishing, 267 pp.

Guyader, O., Berthou, P., Koutsikopoulos, C. et al. (2013) Small scale fisheries in Europe: A comparative analysis based on a selection of case studies. Fisheries Research 140, 1-13.

Hatcher, A. (2000) Subsidies for European Fishing Fleets: the European Community's structural policy for Fisheries 1971-1999. Marine Policy 24, 129-144.

Hauge, K.H., and Wilson, D.C. (Eds.) (2009) Comparative evaluations of innovative fisheries management: Global experiences and European prospects, 1-172. Springer. DOI: 10.1007/978-90-481-2663-7.

Hersoug, B. (2002) New Zealand experience with right-based fisheries management - Unfinished business. Eburon and Delft.

Holden, M. (1994) The Common Fisheries Policy: origin, evaluation and future. Fishing News Books.

ICES (1998) Report of the study group on the precautionary approach to fisheries management. ICES Headquarters, 3-6 February 1998, CM1998 / ACFM:10.

ICES (2004) Report of the ICES Advisory Committee on Fishery Management and Advisory Committee on Ecosystems, 2004. ICES Advice. Volumes 1, Number 2. 
ICES (2005) Report of the ICES Advisory Committee on Fishery Management, Advisory Committee on the Marine Environment and Advisory Committee on Ecosystems, 2005. ICES Advice. Volumes 1-11.

ICES (2006) Report of the ICES Advisory Committee on Fishery Management, Advisory Committee on the Marine Environment and Advisory Committee on Ecosystems, 2006. ICES Advice. Books $1-10$.

ICES (2007) Report of the ICES Advisory Committee on Fishery Management, Advisory Committee on the Marine Environment and Advisory Committee on Ecosystems, 2007. ICES Advice. Books $1-10$.

ICES (2008) Report of the ICES Advisory Committee, 2008. ICES Advice, 2008. Books 1-10.

ICES (2009) Report of the ICES Advisory Committee, 2009. ICES Advice, 2009. Books 1-11.

ICES (2010) Report of the ICES Advisory Committee, 2010. ICES Advice, 2010. Books 1-11.

ICES (2011) Report of the ICES Advisory Committee, 2011. ICES Advice, 2011. Books 1-11.

ICES (2012) Report of the ICES Advisory Committee, 2012. ICES Advice, 2011. Books 1-12.

ICES (2013) Report of the ICES Advisory Committee 2013. ICES Advice, 2013. Books 1-11.

ICES (2014) Report of the ICES Advisory Committee 2013. ICES Advice, 2014. Books 1-11.

ICES (2015a) Report of the North-Western Working Group (NWWG), 28 April-5 May, ICES HQ, Copenhagen Denmark. ICES CM 2015/ACOM:07. 717 pp.

ICES (2015b) Report of the Working Group on the Assessment of Demersal Stocks in the North Sea and Skagerrak (WGNSSK), 28 April-7 May, ICES HQ, Copenhagen, Denmark. ICES CM 2015/ACOM:13. 1031 pp.

Johnson, D., and Haworth, J. (2004) Hooked: the story of the New Zealand fishing industry. Hazard Press Ltd. 
Karagiannakos, A. (1996) Total Allowable Catch (TAC) and quota management system in the European Union. Marine Policy 20, 235-248.

Larabi, Z., Guyader, O., Macher, C. et al. (2013) Quota management in a context of nontransferability of fishing rights: The French case study. Ocean \& Coastal Management 84, $13-22$.

Large, P.A., Agnew, D.J., Alvarez.-Perez, J.A., et al. (2013) Strengths and weaknesses of the management and monitoring of deep-water stocks, fisheries and ecosystems in various areas of the world - a roadmap towards sustainable deep-water fisheries in the Northeast Atlantic? Reviews in Fisheries Science 21, 157-180.

Laurec, A., Biseau, A., and Charuau, A. (1991) Modeling technical interactions. ICES Marine Science Symposia 193, 225-236.

Le Floc ${ }^{e c}$, P., Murillas, A., Aranda, M., et al. (2015) The regional management of fisheries in European Western Waters. Marine Policy 51, 375 - 384

Lindebo, E. (2005) Role of subsidies in EU fleet capacity management. Marine Resource Economics $20,445-466$.

Little, A.S., Needle, C.L., Hilborn, R., Holland, D.S., and Marshall, C.T. (2014) Real-time spatial management approaches to reduce bycatch and discards : experiences from Europe and the United States. Fish and Fisheries DOI: 10.1111/faf.12080.

Mace, P.M., Sullivan, K.J., and Cryer, M. (2014) The evolution of New Zealand's fisheries science and management under ITQs. ICES Journal of Marine Science 71, 204-215.

Madsen, N., (2007) Selectivity of fishing gears in the Baltic Sea cod fishery. Reviews in Fish Biology and Fisheries 17, 517-544.

Marchal, P., Andersen, B., Caillart, B., Eigaard, O., Guyader, O., Hovgaard, H., Iriondo, A., Le Fur, 
F., Sacchi, J., and Santurtún, M. (2007) Impact of technical creeping on fishing effort and mortality for a selection of European fleets. ICES Journal of Marine Science 64, 192-209.

Marchal, P., and Horwood, J. (1996) Long-term targets for the Celtic Sea mixed-species multimétiers fisheries. Aquatic Living Resources 9, 81-94.

Marchal, P., Lallemand, P., Stokes, K., et al. (2009) A comparative review of the fisheries resource management systems in New Zealand and in the European Union. Aquatic Living Resources $22,463-481$.

Ministry for Primary Industries (2013) The status of New Zealand's fisheries 2013, 5pp.

Ministry for Primary Industries (2014a). Fisheries Assessment Plenary, May 2014: stock assessments and stock status. Compiled by the Fisheries Science Group, Ministry for Primary Industries, Wellington, New Zealand. 1381p.

Ministry for Primary Industries (2014b). Fisheries Assessment Plenary May 2014 - Supplement. A Celebration of $30+$ Years of Fisheries Science. Edited by Pamela Mace and Marianne Vignaux, Ministry for Primary Industries, Wellington, New Zealand. 87p.

Minnegal, M.M., and Dwyer, P.D. (2008) Mixed messages: Buying back Australia's fishing industry. Marine Policy 32, 1063-1071.

Motos, L., and Wilson, D.C. (Eds.) (2006) The Knowledge Base for Fisheries Management. Developments in Aquaculture and Fisheries and Aquaculture 36, 1-454.

New Zealand Ministry of Fisheries (2008) Harvest Strategy Standards for New Zealand fisheries. Ministry of Fisheries, October, 25 pp.

New Zealand Ministry of Fisheries (2009) Fisheries 2030: New Zealanders maximizing benefits from the use of fisheries within environmental limits. Ministry of Fisheries, September, 14 pp.

Nielsen, J.R., Ulrich, C., Hegland, T.J. et al. (2013) Critical report of current fisheries management 
measures implemented for the North Sea mixed demersal fisheries. DTU Aqua Report No. 263-2013, $71 \mathrm{pp}$.

OECD (2012) OECD Review of Fisheries: Country Statistics 2012, Éditions OCDE Publishing.

OECD (2013) OECD Review of Fisheries: Country Statistics 2013, Éditions OCDE Publishing.

O־Leary, B.C., Smart, J.C., Neale, F.C. et al. (2011) Fisheries mismanagement. Marine Pollution Bulletin 62, 2642-2648.

Pearce, P.H. (1980) Regulation of fishing effort: with special reference to Mediterranean trawl fisheries, FAO Fish. Tech. Pap. (197), 82 pp.

Plaganyi, E.E., van Putten, I., Hutton, T., et al. (2013) Integrating indigenous livelihood and lifestyle objectives in managing a natural resource. Proceedings of the National Academy of Sciences $110,3639-3644$.

Quillerou, E., Roudaut, N., and Guyader, O. (2013) Managing Fleet Capacity Effectively Under Second-Hand Market Redistribution. Ambio 42, 611-627.

Rayns, N. (2007) The Australian government"s harvest strategy policy. ICES Journal of Marine Science 64, 596-598.

Sanchirico, J.N., Holland, D., Quigley, K., et al. (2006) Catch-quota balancing in multispecies individual fishing quotas. Marine Policy 30, 767-785.

Santiago, J.L., Ballesteros, M.A., Chapela, R., et al. (2015) Is Europe ready for a results-based approach to fisheries management? The voice of stakeholders. Marine Policy 56, 86-97.

Sissenwine, M., and Symes, D. (2007) Report to the General Directorate for Fisheries and Maritime Affairs of the European Commission, 75 pp. URL: http://fishsec.org/downloads/1201534052_04993.pdf.

Sistiaga, M., Herrmann, B., Nielsen, K.N., and Larsen, R.B. (2011) Understanding limits to cod and 
haddock separation using size selectivity in a multispecies trawl fishery: an application of FISHSELECT. Canadian Journal of Fisheries and Aquatic Sciences 68, 927-940.

Smith, A.D.M. (2013) Fishery management: is Europe turning the corner? Current Biology 23, R661662.

Smith, A.D.M., Garcia, S.M. (2014) Fishery management: Contrasts in the Mediterranean and the Atlantic. Current Biology 24, R810-812.

Smith, A.D.M., and Smith, D.C. (2001) A complex quota managed fishery: science and management in Australia's South East Fishery. Marine and Freshwater Research 52, 353-359.

Smith, A.D.M., Fulton, E.J., Hobday, A.J., et al. (2007) Scientific tools to support practical implementation of ecosystem based fisheries management. ICES Journal of Marine Science 64, 633-639.

Smith, A.D.M., Sainsbury, K.J., and Stevens, R.A. (1999) Implementing effective fisheries management systems - management strategy evaluation and the Australian partnership approach. ICES Journal of Marine Science 56, 967-979.

Smith, A.D.M., Smith, D.C., Tuck, G.N., et al. (2008) Experience in implementing harvest strategies in Australia ${ }^{e e}$ s south-eastern fisheries. Fisheries Research 94, 373-379.

Smith, D.C., Punt, A., Dowling, N., et al. (2009) Reconciling approaches to the assessment and management of data-poor species and fisheries with Australiaes Harvest Strategy Policy. Marine and Coastal Fisheries: Dynamics, Management, and Ecosystem Science 1, 244-254.

Squires, D. (2010) A review of fisheries buybacks. Fish and Fisheries 11, 366-387.

Starr, P. (2000) Fishery Management Innovations in New Zealand. Proceedings of the Tenth Biennial Conference of the International Institute of Fisheries Economics and Trade, July 10- 14, 2000, Corvallis, Oregon, USA. Edited by Richard S. Johnston and compiled by Ann L. 
Shriver. International Institute of Fisheries Economics and Trade (IIFET), Corvallis, OR.

STECF (2013a) Scientific, Technical and Economic Committee for Fisheries (STECF) - 2013 Assessment of Mediterranean Sea stocks part I (STECF 13-22). 2013. Publications Office of the European Union, Luxembourg, EUR 26329 EN, JRC 86087, 400 pp.

STECF (2013b) Scientific, Technical and Economic Committee for Fisheries (STECF) - The 2013 Annual Economic Report on the EU Fishing Fleet (STECF-13-15). Publications Office of the European Union, Luxembourg, EUR 26158 EN, JRC 84745, 302 pp.

STECF (2013c) Assessment of balance indicators for key fleet segments and review of national reports on Member States efforts to achieve balance between fleet capacity and fishing opportunities. Scientific, Technical and Economic Committee for Fisheries (STECF). Publications Office of the European Union, Luxembourg, 140 pp.

STECF (2014a) Scientific, Technical and Economic Committee for Fisheries (STECF) - 2013 Assessment of Mediterranean Sea stocks part II (STECF-14-08). 2013. Publications Office of the European Union, Luxembourg, EUR 26614 EN, JRC 89860, 364 pp.

STECF (2014b) Scientific, Technical and Economic Committee for Fisheries (STECF) - Evaluation of Fishing Effort Regimes in European Waters - Part 2 (STECF-14-20). Publications Office of the European Union, Luxembourg, EUR 27027 EN, JRC 93183, 844 pp.

Stokes, T.K., Gibbs, N., and Holland, D. (2006) New Zealand's cost recovery regime for fisheries research services: an industry perspective. Bulletin of Marine science 78, 467-485.

Ulrich, C., Reeves, S.A., Vermard, Y., et al. (2011) Reconciling single-species TACs in the North Sea demersal fisheries using the Fcube mixed-fisheries advice framework. ICES Journal of Marine Science 68, 1535-1547.

UN (1972) Report of the United Nations Conference on the Human Environment. Stockholm, Sweden, 5-16 June 1972. 
UN (1992) Report of the United Nations Conference on Environment and Development. Rio de Janeiro, Brazil, 3-14 June 1992.

UN (2002) Report of the World Summit on Sustainable Development. Johannesburg, South Africa, 26 August - 4 September 2002.

UN (2012) Report of the United Nations Conference on Sustainable Development. Rio de Janeiro, Brazil, 20-22 June 2012.

Van Hoof, L. (2010) Tools for fishing fleet management. European Parliament study, Directorate General for Internal Policies, Policy Department B: Structural and Cohesion Policies Fisheries, $61 \mathrm{pp}$.

Vasilakopoulos, P., Maravelias, C.D., and Tserpes, G. (2014) Europe ${ }^{e e}$ s skeleton in the closet, the steady decline of Mediterranean fish stocks. Current Biology 24, 1643-1648.

Viana, M., Graham, N., Wilson, J.G., et al. (2011) Fishery discards in the Irish Sea exhibit temporal oscillations and trends reflecting underlying processes at an annual scale. ICES Journal of Marine Science 68, 221-227.

Vinther, M., Reeves, S.A., and Patterson, K.R. (2004) From single-species advice to mixed-species management: taking the next step. ICES Journal of Marine Science 61, 1398-1409.

Woodhams, J., Vieira, S., and Stobutzki, I. (eds) (2013) Fishery status reports 2012, Australian Bureau of Agricultural and Resource Economics and Science, Canberra.

Yandle, T., and Dewees, C.M. (2008) Consolidation in an individual transferable quota regime: lessons from New Zealand. Environmental Management 41, 915-928. 
Table 1. Main fisheries statistics and indicators for the EU, Iceland, New Zealand and Australia, including fleet size, employment in harvest sector, landed value, trade and government transfers. Different time periods have been considered depending on data availability. Information was occasionally missing in some years for a number of countries, so the indicators were averaged over the whole time period.

\begin{tabular}{|c|c|c|c|c|c|}
\hline & & $\mathbf{E U}$ & Iceland & New Zealand & Australia \\
\hline EEZ $\left(\right.$ million $\left.\mathrm{km}^{2}\right)$ & & 25 & 0.8 & 7 & 9 \\
\hline \multirow[t]{2}{*}{ No. vessels $(2008-2012)^{1}$} & Average & 83,611 & 1,619 & 1,414 & 325 \\
\hline & Mean inter-annual change & $-2 \%$ & $+2 \%$ & $0 \%$ & $-1 \%$ \\
\hline \multirow[t]{2}{*}{ Employment harvest sector $(2009-2011)^{2}$} & Average & 131,525 & 4,933 & 1,780 & 7,521 \\
\hline & Mean inter-annual change & $-3 \%$ & $+21 \%$ & $-2 \%$ & $-5 \%$ \\
\hline Total landed value $(2005-2012)^{3}$ & Million US \$ & 8,141 & 1,158 & 275 & 1,187 \\
\hline \multirow[t]{3}{*}{ Trade $(2005-2012)^{3}$} & Imports (Million US \$) & 22,855 & 96 & 102 & 1,137 \\
\hline & Exports (Million US \$) & 4,051 & 1,951 & 907 & 924 \\
\hline & Balance (Million US \$) & $-18,804$ & $+1,855$ & 805 & -213 \\
\hline \multirow[t]{4}{*}{ Government transfers $(2005-2012)^{3}$} & Total (Million US \$) & 1,123 & 24 & 40 & 36 \\
\hline & Proportion of landing value (\%) & $14 \%$ & $2 \%$ & $15 \%$ & $3 \%$ \\
\hline & Subsidies ( $\%$ of total transfers) & $50 \%$ & $27 \%$ & $0 \%$ & $0 \%$ \\
\hline & Cost recovery $(\%)$ & $0 \%$ & $65 \%$ & $39 \%$ & $36 \%$ \\
\hline
\end{tabular}

${ }^{1}$ Adapted from : EU, Iceland (EUROSTAT 2013); Australia, New Zealand (OECD 2013)

2 Adapted from : EU (STECF 2011 ; STECF 2012d ; STECF 2013c) ; Iceland, Australia, New Zealand (OECD 2012; OECD 2013)

${ }^{3}$ Adapted from OECD (2013) 
Table 2. Summary of the key similarities and differences of the fishery management systems in the EU, Iceland, New Zealand and Australia.

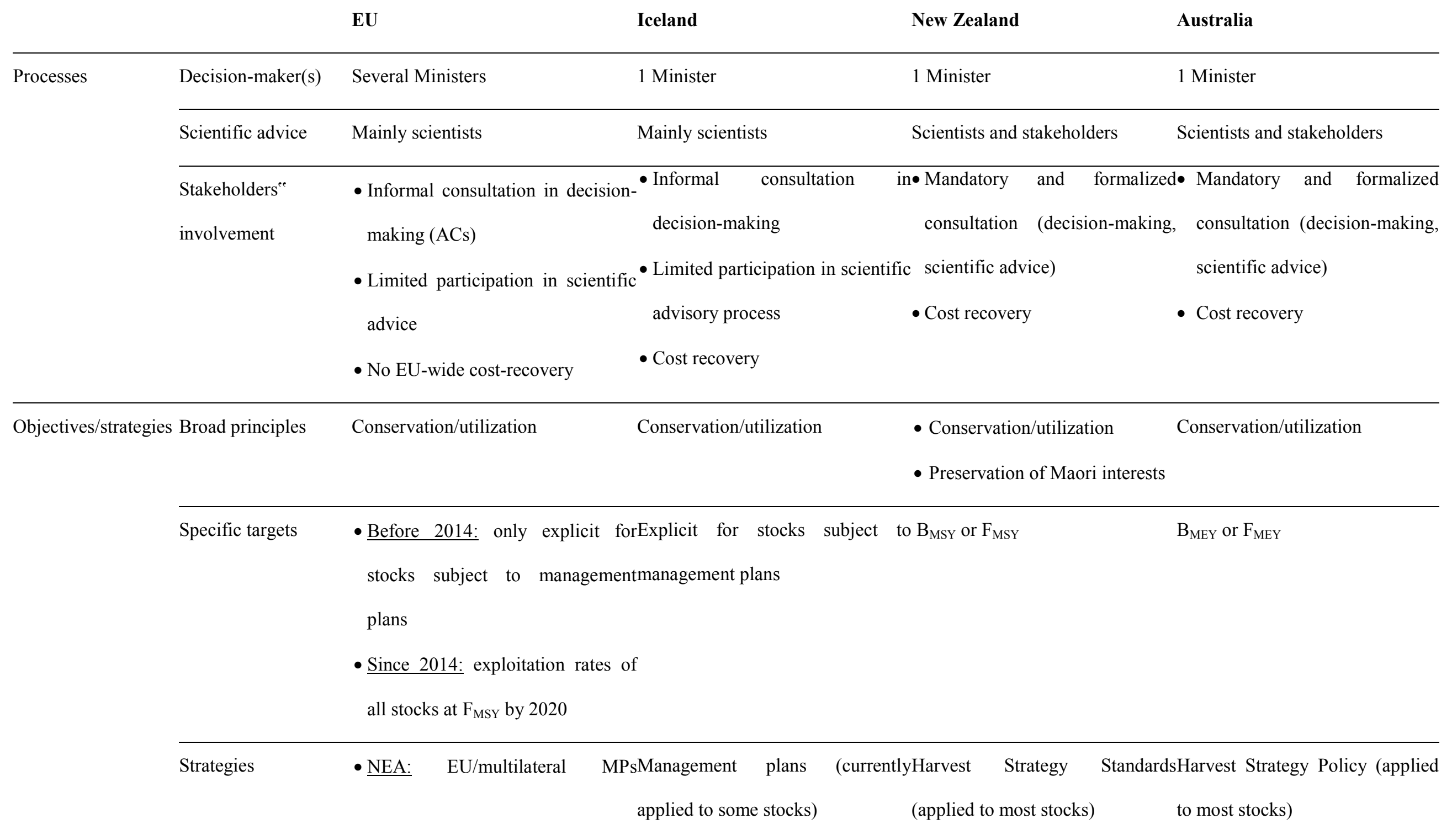


(applied to some stocks)

- Mediterranean: National MPs

(applied to some fisheries)

\begin{tabular}{|c|c|c|c|c|c|}
\hline \multirow[t]{4}{*}{ Tools } & Conservation & - TAC (except in Mediterranean) & $\bullet \mathrm{TAC}$ & TAC (includes recreational & $\& \bullet \mathrm{TAC}$ \\
\hline & & $\begin{array}{l}\text { - Technical measures } \\
\text { - Effort limits }\end{array}$ & - Technical measures & customary allowance) & - Input control measures \\
\hline & Access & - Fishing licenses/permits & - Fishing licenses/permits & - Fishing licenses/permits & - Fishing licenses/permits \\
\hline & & • No EU-wide ITQ system & - ITQs widespread & - ITQs widespread & - ITQs in some fisheries \\
\hline
\end{tabular}


1 Table 3. Conservation indicators for the different regions under investigation: stock information

2 (total number of stocks; total number (and proportion) of stocks for which spawning stock biomass 3 (SSB) and fishing mortality (F) have been estimated relative to limit reference points $\mathrm{SSB}_{\text {lim, }}, \mathrm{F}_{\text {lim }}$, 4 respectively) and stock status (number (and proportion) of stocks for which $\mathrm{SSB}>\mathrm{SSB}_{\lim }$ and $\mathrm{F}<$ $5 \mathrm{~F}_{\text {lim). }}$. The results of Chi-square tests comparing stock statuses across regions (with or without 6 Mediterranean stocks) are shown; $(*) \mathrm{p}<0.05 ;(* *) \mathrm{p}<0.01 ;(* * *) \mathrm{p}<0.001$.

\begin{tabular}{lllll}
\hline Country / Ecoregion & \multicolumn{2}{c}{ Stock information } & \multicolumn{2}{c}{ Stock status } \\
\cline { 2 - 5 } & SSB informed & F informed & SSB $>$ SSB $_{\text {lim }}$ & F $<\mathrm{F}_{\text {lim }}$ \\
\hline EU Northeast Atlantic (2013) & 35 & 19 & $25(71 \%)$ & $13(68 \%)$ \\
EU Mediterranean Sea (2013) & 0 & 24 & - & $2(8 \%)$ \\
Iceland and East Greenland (2013) & 5 & 3 & $5(100 \%)$ & $3(100 \%)$ \\
New Zealand (2013) & 139 & 117 & $114(82 \%)$ & $96(82 \%)$ \\
Australia - Federal stocks (2012) & 72 & 81 & $63(88 \%)$ & $77(95 \%)$ \\
\hline$\chi^{2}$ (with Mediterranean stocks) & & & 4.14 & $83.78^{* * *}$ \\
$\chi^{2}$ (without Mediterranean stocks) & & & 4.14 & $11.70^{* *}$ \\
\hline
\end{tabular}


10 Table 4. Marine fish and shellfish stocks managed by TACs in EU waters (periods 2002-2006 and

11 2010-2013) and Icelandic waters (2010-2013). Frequency (proportion of years*stocks) of: TACs

12 above advised catches. The results of tests comparing frequencies between periods for EU stocks,

13 and between regions after 2010 are shown; $(*) \mathrm{p}<0.05$.

\begin{tabular}{llll}
\hline Country & Period & N & TAC > Advised catch \\
\hline EU Northeast Atlantic & $2002-2006$ & 339 & $67 \%$ \\
EU Northeast Atlantic & $2010-2013$ & 249 & $59 \%$ \\
Iceland & $2010-2013$ & 37 & $59 \%$ \\
\hline$\varepsilon$ (between periods) & & & $2.00^{*}$ \\
$\varepsilon$ (between regions) & & 0.00 \\
\hline
\end{tabular}

14

15 Table 5. Marine fish and shellfish stocks managed by TACs in EU waters (2010-2013), Icelandic 16 waters (2010-2013), off Australia (2010-2014) and New Zealand (2010-2014). Frequency

17 (proportion of years*stocks) of: realized catches above catch limit, realized catches above catch limit

$18+10 \%$. The results of a Chi-square test comparing frequencies between regions after 2010 are shown;

$19 \quad(*) \mathrm{p}<0.05 ;(* *) \mathrm{p}<0.01 ;(* * *) \mathrm{p}<0.001$.

\begin{tabular}{lllll}
\hline Country & Period & N & Catch $>$ TAC & Catch $>1.1 \times$ TAC \\
\hline EU Northeast Atlantic & $2010-2013$ & 411 & $27 \%$ & $18 \%$ \\
Iceland & $2010-2013$ & 42 & $57 \%$ & $12 \%$ \\
Australia & $2010-2014$ & 215 & $3 \%$ & $0 \%$ \\
New Zealand & $2010-2014$ & 2490 & $6 \%$ & $2 \%$ \\
\hline$\chi^{2}$ & & & $309.33^{* * *}$ & $115.60^{* * *}$
\end{tabular}


Figure 1. Annual variations in the proportion of stocks managed in the EU (empty squares), New Zealand (stars) and Australia (black dots), for which (a) biomass $\mathrm{B}>\mathrm{B}_{\mathrm{lim}}$ and (b) fishing mortality $\mathrm{F}$ $<\mathrm{F}_{\text {lim. }}$.
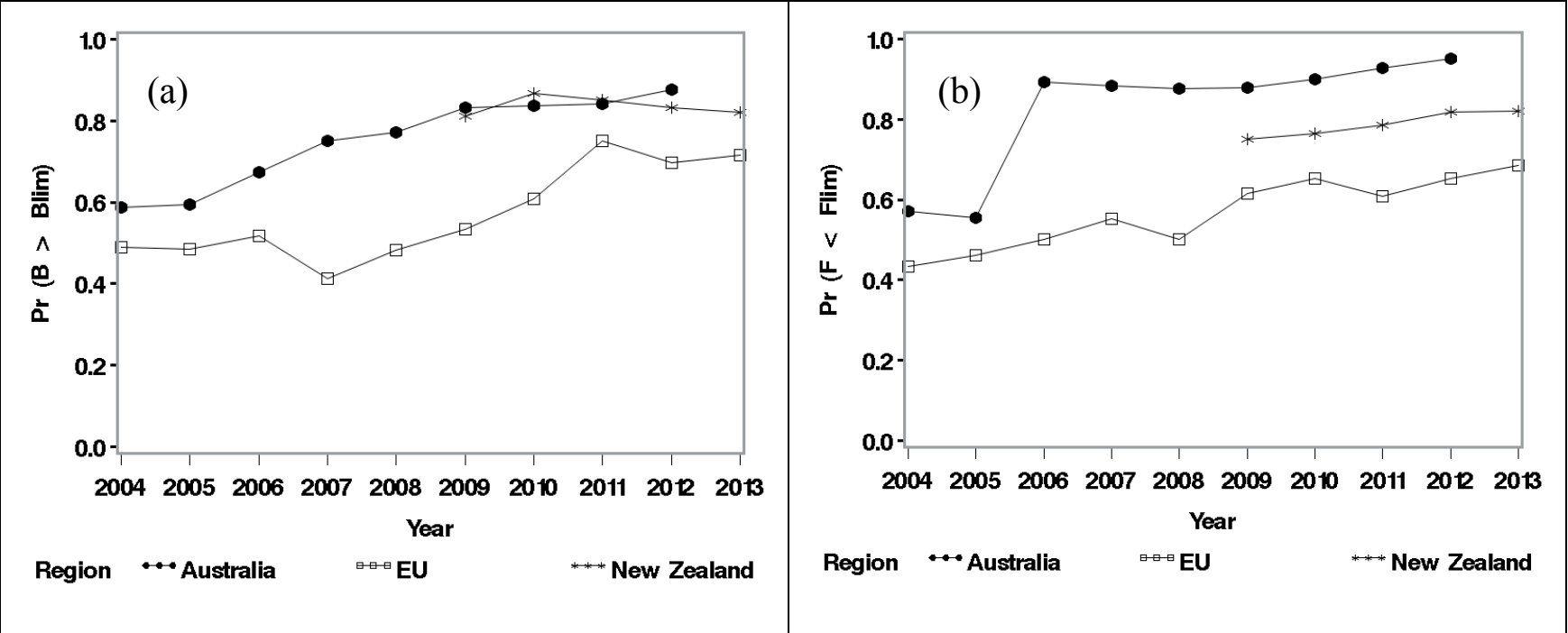
Figure 2. Representations of: (a, c) catch options advised by ICES versus agreed TAC; (b, d) Catch estimated by ICES versus agreed TAC; $(a, b)$ EU Northeast Atlantic stocks over the period 20102013; (c, d) Icelandic stocks over the period 2010-2013. The dotted line represents the 1:1 relation between advised catches and TACs.

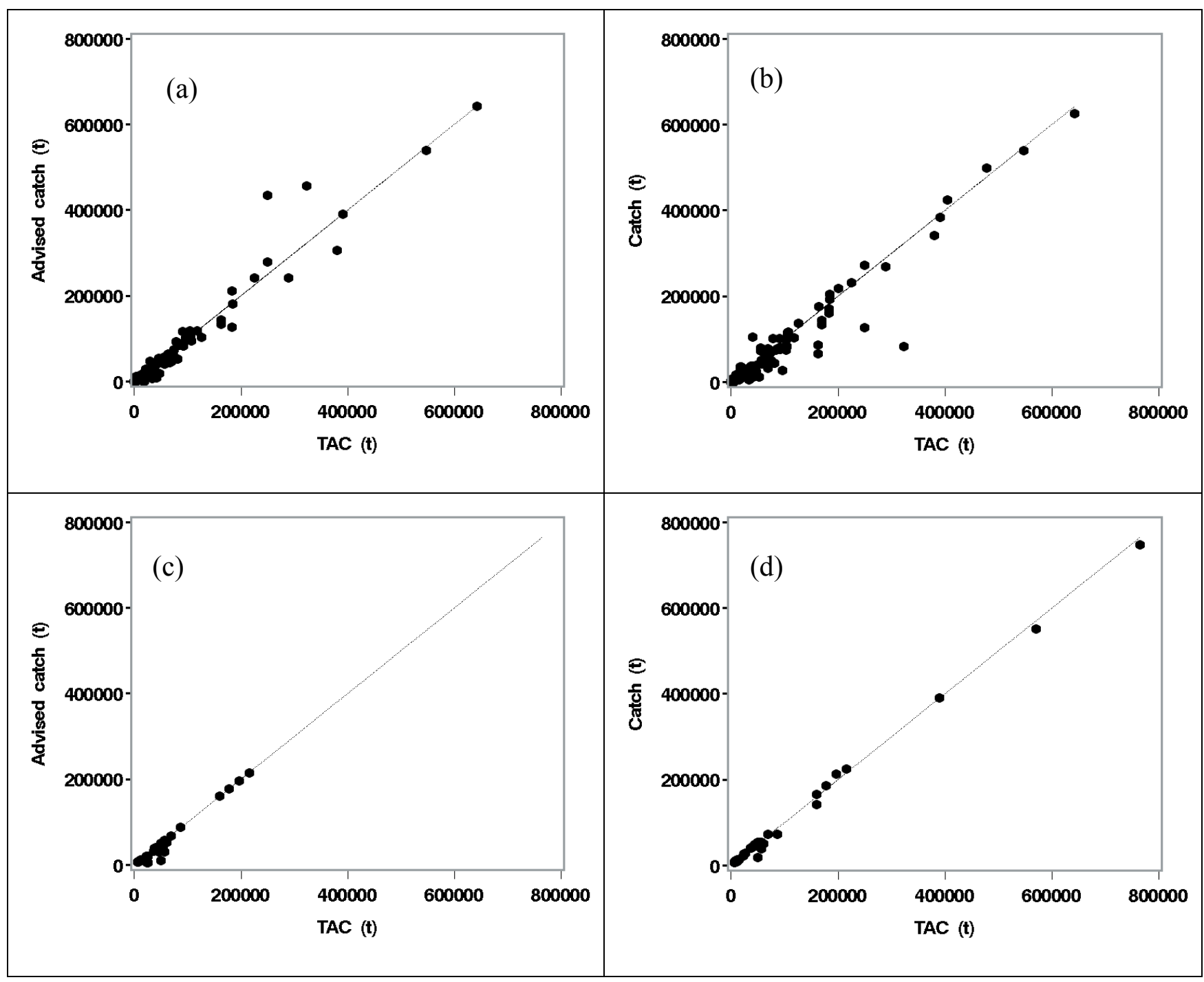

